\title{
Effect of dietary tannins on the performance, lymphoid organ weight, and amino acid ileal digestibility of broiler chickens: A meta-analysis
}

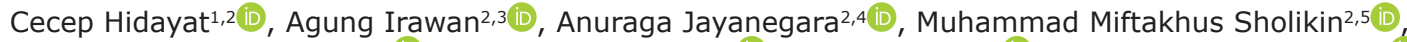 \\ Tri Rachmanto Prihambodo 2,5 (D), Yulianri Rizki Yanza2,6(D), Elizabeth Wina1 ${ }^{(\mathbb{D})}$, Sadarman Sadarman ${ }^{2,7,8}$ (i), \\ Rantan Krisnan ${ }^{1,2}$ (i) and Isbandi Isbandi ${ }^{1}$ (D)
}

1. Indonesian Research Institute For Animal Production, Ciawi Bogor 16720, Indonesia; 2. Animal Feed and Nutrition Modelling Research Group, Faculty of Animal Science, IPB University, Bogor 16680, Indonesia; 3. Vocational School, Universitas Sebelas Maret, Surakarta 57126, Indonesia; 4. Department of Nutrition and Feed Technology, Faculty of Animal Science, IPB University, Bogor 16680, Indonesia; 5. Graduate Study Program of Nutrition and Feed Science, Faculty of Animal Science, IPB University, Bogor 16680, Indonesia; 6. Department of Animal Nutrition, Faculty of Veterinary Medicine and Animal Science, Poznan University of Life Sciences, Poznań 60-637, Poland; 7. Department of Animal Science, Sultan Syarif Kasim State Islamic University, Pekanbaru 28293, Indonesia; 8. Center for Livestock Studies and Development, Pahlawan Tuanku Tambusai University, Bangkinang 28412, Indonesia.

Corresponding author: Cecep Hidayat, e-mail: hidayat_c2p@yahoo.com

Co-authors: AI: a.irawan@staff.uns.ac.id, AJ: anuraga.jayanegara@gmail.com, MMS: mohammadmiftakhussholikin@gmail.com, TRP: rachprihambodo@gmail.com, YRY: yanza.pulspoznan@gmail.com, EW: winabudi@yahoo.com,

SS: sadarman@uin-suska.ac.id, RK: ran_tania@yahoo.com, II: isbandi.balitnak2021@gmail.com

Received: 24-01-2021, Accepted: 15-04-2021, Published online: 01-06-2021

doi: www.doi.org/10.14202/vetworld.2021.1405-1411 How to cite this article: Hidayat C, Irawan A, Jayanegara A, Sholikin MM, Prihambodo TR, Yanza YR, Wina E, Sadarman S, Krisnan R, Isbandi I (2021) Effect of dietary tannins on the performance, lymphoid organ weight, and amino acid ileal digestibility of broiler chickens: A meta-analysis. Veterinary World, 14(6): 1405-1411.

\begin{abstract}
Background and Aim: Tannins are functional secondary metabolites that may provide benefits to ruminants. However, to date, their effects on broiler chickens remain inconclusive. This study aimed to evaluate the effectiveness of dietary tannin levels on the performance, body organs, and amino acid (AA) digestibility of broiler chickens using a meta-analysis.

Materials and Methods: After verification and evaluation, a total of 22 articles were included in the present study. All data regarding dietary tannin dosages, performance, digestibility, and gastrointestinal physiology of broiler chickens were tabulated into a database. The database data were then statistically analyzed using mixed models, with tannin dose as a fixed effect and study as a random effect.

Results: High levels of dietary tannins negatively affected the average daily gain and average daily feed intake of broiler chickens according to linear patterns $(\mathrm{p}<0.001)$. In addition, dietary tannins decreased drumstick and liver weights, as well as bursa of Fabricius and spleen weight $(\mathrm{p}<0.05)$. Meanwhile, other carcass traits (i.e., thigh, wings, and body fat) were not influenced by dietary tannins. Regarding AA digestibility, high dietary tannin concentrations induced negative responses on isoleucine, leucine, and methionine digestibility $(\mathrm{p}<0.05)$.
\end{abstract}

Conclusion: Dietary tannins appear to have a negative effect on broiler performance, lymphoid organ weight, and AA ileal digestibility. Hence, the addition of tannins to broiler diets is not recommended.

Keywords: amino acid ileal digestibility, broiler chicken, meta-analysis, tannin.

\section{Introduction}

In the past decade, there has been intense discussion regarding an increased demand for functional food derived from broiler chickens. Since a global ban on the use of antibiotics as growth promoters, there has been a driving effort to utilize natural substances as feed additives in broiler production $[1,2]$. The use of growth promoters causes resistance to microbes, such that they are no longer effective in killing microorganisms of similar species [3]. Several alternatives have been evaluated by both farmers and researchers,

Copyright: Hidayat, et al. Open Access. This article is distributed under the terms of the Creative Commons Attribution 4.0 International License (http://creativecommons.org/licenses/ by/4.0/), which permits unrestricted use, distribution, and reproduction in any medium, provided you give appropriate credit to the original author(s) and the source, provide a link to the Creative Commons license, and indicate if changes were made. The Creative Commons Public Domain Dedication waiver (http:// creativecommons.org/publicdomain/zero/1.0/) applies to the data made available in this article, unless otherwise stated. with mixed results. Plant bioactive substances and their constituents are known to have medicinal abilities [4,5]. Since 1995, the use of plants as an alternative treatment to improve the health of animals has been referred to as naturopathy; tannins are a potentially useful compound since they have been widely recognized for their positive effects in some animal species, particularly ruminants.

Despite their antibacterial [6], anti-inflammatory [7], and antiviral [8] effects, plants containing tannins have not been widely used as feed additives in broiler chickens. Tannins are contained in several feed ingredients commonly used in broiler diets, such as sorghum and barley. Tannins are produced by green plants in different levels and qualities. In broiler chickens, the inclusion of up to $3 \%$ dietary tannins can improve gut health and digestive performance [9-11]. Unlike in ruminant animals, the mode of action of tannins in broiler chickens has not been fully 
characterized [9]. The previous studies have found inconsistent results: Some studies have demonstrated a positive effect of the addition of tannins in terms of improved performance, digestibility [12], and organ health [13], whereas other studies have reported negative effects due to their addition.

Because of the variability of results across different experiments, the data from various studies must be summarized to reach a robust conclusion concerning the effects of tannins on broilers. Therefore, this study aimed to evaluate the effectiveness of dietary tannin levels on the performance, organweight, and digestibility of broiler chickens using a meta-analysis methodology.

\section{Materials and Methods}

\section{Ethical approval} study.

Ethical approval is not necessary for this type of

\section{Database development}

All the data used in the present study were collected from published articles and recorded in a database. Published articles were browsed using multiple search engines for scientific papers, such as Google Scholar, Scopus, Web of Science, PubMed, and Mendeley, using the keywords "tannin" and "broiler." Approximately 187 articles were retrieved that outlined studies of tanning supplementation for broilers, yet only 120 articles of these articles showed potential for inclusion on the basis of their title and abstract. The parameters included were (1) broiler chicken performance: Average daily gain (ADG), feed intake (FI), feed conversion ratio (FCR), mortality, and carcass cut weight and (2) broiler chicken gastrointestinal physiology and digestibility: The weight of lymphoid organs, tibia minerals, nutrient digestibility, intestinal histomorphometry, and malondialdehyde concentration.

After careful evaluation, 22 articles were selected for inclusion in the database (Table-1) [12,14-34]. The selected articles confirmed that several forms of tannins have been used to supplement broiler diets, such as total tannins, condensed tannin, hydrolysable tannin, and tannic acid. Broiler chickens were mostly fed with a corn-soybean meal-based diet. Tannins were supplemented at a $0-30 \mathrm{~g} / \mathrm{kg}$ of diet. Tannin supplementation dosages and their typical source were compiled in the database. Performance parameters such as ADG and FI were also compiled in the database, expressed as g/bird/day unit. Mortality and digestibility were expressed as percentages $(\%)$. If any data used a different measurement unit (e.g., $\% \mathrm{v} / \mathrm{v}$ or $\% \mathrm{w} / \mathrm{v})$, these data were transformed into the above measurement units for consistency. Once all data for dietary tannin dosages, performance, digestibility, and gastrointestinal physiology of broiler chickens were established, the database was statistically analyzed.

\section{Statistical analysis}

Data with compatible measurement units were processed for statistical analysis using a mixed model procedure for meta-analysis [35,36,37]. The analysis was run with SAS version 9.1 using the PROC MIXED procedure. Tannin supplementation level was set as a fixed effect, whereas the study was set as a random effect; thus, the analysis included a RANDOM statement. Statistical significance was set at $\mathrm{p}<0.05$, whereas a trend was set $\mathrm{p}=0.05-0.10$.

The tannins levels were treated as continuous predictor where the response variables were regressed using the following mathematical model:

$$
Y_{i j}=B_{0}+B_{I} X_{i j}+s_{i}+b_{i} X_{i j}+e_{i j}
$$

Where, $Y_{i j}=$ dependent variable; $B_{0}=$ overall intercept across all studies (fixed effect); $B_{1}=$ linear regression coefficient of $\mathrm{Y}$ on $\mathrm{X}$ (fixed effect); $X_{i \mathrm{j}}=$ tannin supplementation as the continuous predictor; $s_{i}=$ value of random effect of study $i ; b_{i}=$ random effect of study on the regression coefficient of $\mathrm{Y}$ on $\mathrm{X}$ in study $i$; and $e_{i j}=$ the unexplained residual error.

\section{Results}

All of the evaluated additions affected growth performance, lymphoid organ weight, and amino acid (AA) ileal digestibility, compared with the control group (Table-2). Broilers gained 42.12 $\pm 27.68 \mathrm{~g} / \mathrm{bird} /$ day, with an average daily FI (ADFI) of $76.14 \pm 50.66 \mathrm{~g} / \mathrm{bird} /$ day, resulting in an FCR of $1.942 \pm 0.468$.

The use of tannins as a feed additive had various effects on carcass parameters. Drumstick, thighs, and wings accounted for $7.96 \%, 11.53 \%$, and $6.25 \%$ of thetotal carcass weight, respectively, followed by abdominal fatand liver parts at $1.37 \%$ and liver at $2.63 \%$. Differences between the minimum and maximum values for carcass composition parameters were 3.54-fold for thighs, 1.96-fold for drumsticks, 3.13fold for wings, 3.09-fold for fat, and 1.69-fold for the liver. Carcass composition was widely different for each broiler because of different strains and ages. In addition, the carcass composition and growth performance of broilers treated with tannin showed various results, as shown by the minimum and maximum values for each parameter. For the bursa and spleen, minimum and maximum values ranged from $0.22 \%$ to $3.2 \%$ and $0.1 \%$ to $2.4 \%$, respectively. Conversely, tannins have little effect on digestibility. There was little variation in AA ileal digestibility wherethe largest difference in digestibility was threonine.

Table- 3 presents the parameter estimates of the effect of dietary tannin levels on broiler performance, lymphoid organs, and AA digestibility. The present meta-analysis revealed that increasing dietary tannin levels had a negative effect on broiler ADG and ADFI, as shown by the linear decrease in the slopes $(\mathrm{p}<0.001$; (Table-3); however, it did not affect FCR $(p=0.47)$. In addition, increasing dietary tannin levels decreased drumstick and liver weight, as well as 
Table-1: Studies included in the meta-analysis.

\begin{tabular}{|c|c|c|c|c|c|}
\hline \multicolumn{2}{|c|}{ No. Reference } & \multicolumn{2}{|c|}{ Period (d)Tannin source } & \multirow{2}{*}{$\begin{array}{l}\text { Tannin form } \\
\text { Tannic acid }\end{array}$} & \multirow{2}{*}{$\frac{\text { Dose }(\mathbf{g} / \mathbf{k g})}{0 \mathrm{sd} 30}$} \\
\hline 1 & Ramah et al. [14] & 35 sd 42 & Commercial tannic acid & & \\
\hline 2 & Mannelli et al. [15] & 1 sd 35 & Extracted from the wood of $C$. sativa & Hydrolysable tannin & $0 \mathrm{sd} 2.7$ \\
\hline 3 & Manyelo et al. [16] & 1 sd 21 & S. bicolor & Condensed tannin & 0 sd 1.2 \\
\hline 4 & Saleh et al. [17] & 15 sd 27 & Sorghum & Unspecified & 0 sd 3.1 \\
\hline 5 & Bayerle et al. [18] & 21 sd 42 & Black wattle tannin (Acacia mearnsii) & Tannic acid & 0 sd 0.9 \\
\hline 6 & Tomaszewska et al. [19] & 1 sd 21 & Faba bean (FB) seeds ( $V$. faba L. minor) & Unspecified & 0 sd 1.6 \\
\hline 7 & Abdulla et al. [20] & 13 sd 21 & Field beans ( $V$. faba L. var. minor) & Condensed tannin & 0 sd 1.86 \\
\hline 8 & Bayerle et al. [21] & 1 sd 21 & Wattle tannin (tannin acid $72 \%$ ) & Tannic acid & 0 sd 0.9 \\
\hline 9 & Xu et al. [22] & 1 sd 21 & S. bicolor L. Moench & Unspecified & 0 sd 2.54 \\
\hline 10 & Abdulla et al. [23] & 7 sd 16 & Field beans (V. faba L. var. minor) & Unspecified & 0 sd 25.4 \\
\hline 11 & Batonon-Alavo et al. [24] & 8 sd 15 & Sorghum, cottonseed meal, and millet & Condensed tannin & 0 sd 0.89 \\
\hline 12 & Hu et al. [25] & $1 \mathrm{~d} 42$ & Fermented rapeseed meal & Unspecified & 0 sd 1.4 \\
\hline 13 & Starčević et al. [26] & 1 sd 35 & Commercial tannic acid & Tannic acid & 0 sd 5 \\
\hline 14 & Hejdysz et al. [27] & 1 sd 21 & Pea $(P$. sativum $)$ & Unspecified & 0 sd 0.030 \\
\hline 15 & Riasi et al. [28] & 1 sd 42 & Pea seed (Lathyrus sativus) & Unspecified & 0 sd 0.82 \\
\hline 16 & Rezar and Salobir [29] & 28 sd 33 & Sweet chestnut (C. sativa Mill.) wood extract & Unspecified & 0 sd 1.5 \\
\hline 17 & Tandiang et al. [12] & 1 sd 21 & Sorghum & Condensed tannin & 0 sd 1.32 \\
\hline 18 & Konieczka et al. [30] & 8 sd 15 & Peas ( $P$. sativum L.) & Unspecified & 0 sd 0.76 \\
\hline 19 & Torres et al. [31] & 1 sd 42 & Sorghum & Unspecified & 0 sd 2.87 \\
\hline 20 & $\begin{array}{l}\text { Sasipriya and } \\
\text { Siddhuraju [32] }\end{array}$ & 1 sd 21 & $\begin{array}{l}\text { Entada scandens, Canavalia gladiata, and } \\
\text { Canavalia ensiformis }\end{array}$ & Unspecified & 0 sd 0.0525 \\
\hline 21 & Teteh et al. [33] & 1 sd 28 & Moringa oleifera & Unspecified & 0 sd 0.40 \\
\hline 22 & Brus et al. [34] & 28 sd 42 & Chestnut tannins & Hydrolysable tannin & 0 sd 0.2 \\
\hline
\end{tabular}

C. sativa=Castanea sativa, $P$. sativum=Pisum sativum, S. bicolor=Sorghum bicolor, $V$. faba=Vicia faba

Table-2: Summary of the descriptive statistics of the studies included.

\begin{tabular}{|c|c|c|c|c|c|}
\hline $\begin{array}{l}\text { Response } \\
\text { parameters }\end{array}$ & Unit & Mean & SD & Max & Min \\
\hline \multicolumn{6}{|l|}{ Performance } \\
\hline $\begin{array}{l}\text { Average daily } \\
\text { gain }\end{array}$ & g/bird/day & 42.12 & 27.68 & 92.71 & 6.56 \\
\hline $\begin{array}{l}\text { Average daily } \\
\text { feed intake }\end{array}$ & g/bird/day & 76.14 & 50.66 & 189 & 10.73 \\
\hline $\begin{array}{l}\text { Feed conversion } \\
\text { ratio }\end{array}$ & no unit & 1.942 & 0.468 & 3.48 & 0.97 \\
\hline Thigh & $\%$ & 7.958 & 4.782 & 14.17 & 4.00 \\
\hline Drumstick & $\%$ & 11.53 & 2.889 & 15.38 & 7.86 \\
\hline Wing & $\%$ & 6.295 & 3.295 & 10.7 & 3.44 \\
\hline Fat & $\%$ & 1.369 & 0.572 & 2.35 & 0.76 \\
\hline Liver & $\%$ & 2.628 & 0.631 & 4.81 & 2.15 \\
\hline \multicolumn{6}{|c|}{ Lymphoid organ weight } \\
\hline Bursa & $\%$ & 0.689 & 0.92 & 3.2 & 0.22 \\
\hline Spleen & $\%$ & 0.458 & 0.77 & 2.4 & 0.10 \\
\hline \multicolumn{6}{|c|}{ Amino acid ileal digestibility } \\
\hline Lysine & $\%$ & 87.8 & 1.643 & 89 & 85 \\
\hline Threonine & $\%$ & 72.4 & 13.59 & 96 & 64 \\
\hline Isoleucine & $\%$ & 82.2 & 2.683 & 85 & 78 \\
\hline Leucine & $\%$ & 82 & 5.523 & 87 & 73 \\
\hline Phenylalanine & $\%$ & 84.2 & 4.147 & 87 & 77 \\
\hline Arginine & $\%$ & 80.2 & 6.221 & 87 & 70 \\
\hline Methionine & $\%$ & 88.4 & 3.209 & 92 & 84 \\
\hline
\end{tabular}

$\mathrm{SD}=$ Standard of deviation, Max $=$ Maximum value Min=Minimum value

negatively affecting the bursa Fabricius and spleen weights $(p<0.05)$. Meanwhile, other carcass traits (i.e., thighs, wings, and body fat) were not influenced by the inclusion of dietary tannins. In terms of AA digestibility, as the dietary concentration of tannins increased, it had a negative effect on isoleucine, leucine, and methionine digestibility, as shown by their negative slopes (Table-3). Other essential AA such as lysine, threonine, and arginine were not influenced by tannin levels.

\section{Discussion}

Among the entire dataset, the performance of broiler chickens was fairly good, as indicated by an ADG of $42.12 \pm 27.68 \mathrm{~g} /$ bird/day and an FCR of $1.94 \pm 0.47$. This performance was nearly similar to that noted in the meta-analysis conducted by LétourneauMontminy et al. [38]. The values for other variables such as carcass traits, lymphoid organs, and AA digestibility were also within the normal range [39].

In this meta-analysis, broilers had an average ADG of $42.12 \pm 27.68 \mathrm{~g} / \mathrm{bird} /$ day, based on an average ADFI of $76.14 \pm 50.66 \mathrm{~g} / \mathrm{bird} /$ day, resulting in an average FCR of 1.942. These results are comparable with the ADG, ADFI, and FCR of broiler chickens generally. Under normal conditions, at 35 days of age, Cobb and Ross strain 408 broilers have an ADG of 63.86 and $65.3 \mathrm{~g} / \mathrm{bird} /$ day, respectively, based on an ADFI of 179 and $185 \mathrm{~g} / \mathrm{bird} /$ day, respectively, leading to an FCR of 1.5 and 1.473. A similar variation was also noted for carcass components. Average values for thighs, drumsticks, and wings were $7.958 \%$, $11.53 \%$, and $6.25 \%$ of their total carcass weight, respectively, followed by fat and liver percentage values of $1.369 \%$ and $2.628 \%$. Since the present study was comprised of multiple experiments, it is generally accepted that there were large variations among parameter estimates due to the difference in length of the experiments used. The high heterogeneity can be observed from the minimum and maximum values for both growth performance and carcass composition parameters, there was wide variation in the results (Table-2). 
Table-3: The effects of tannin supplementation levels on performance, lymphoid organ weight, carcass cuts weight, and amino acid ileal digestibility of broiler chickens.

\begin{tabular}{|c|c|c|c|c|c|c|c|c|c|c|c|}
\hline $\begin{array}{l}\text { Response } \\
\text { parameters }\end{array}$ & Unit & Model & $\mathbf{N}$ & Intercept & SE intercept & Slope & SE slope & p-value & RMSE & AIC & Trend \\
\hline \multicolumn{12}{|l|}{ Performance } \\
\hline Average daily gain & $\begin{array}{l}\text { g/bird/ } \\
\text { day }\end{array}$ & $\mathrm{L}$ & 68 & 46.23 & 5.67 & -4.87 & 1.13 & $<0.001$ & 1.75 & 480.50 & Negative \\
\hline $\begin{array}{l}\text { Average daily feed } \\
\text { intake }\end{array}$ & $\begin{array}{l}\text { g/bird/ } \\
\text { day }\end{array}$ & $L$ & 65 & 84.76 & 11.52 & -9.62 & 1.97 & $<0.001$ & 1.83 & 532.94 & Negative \\
\hline Feed conversion ratio & No unit & $\mathrm{L}$ & 65 & 1.88 & 0.11 & 0.04 & 0.05 & 0.47 & 2.06 & 41.41 & Positive \\
\hline Thigh & $\%$ & $\mathrm{~L}$ & 16 & 7.60 & 3.18 & -0.81 & 1.54 & 0.61 & 1.12 & 25.35 & Negative \\
\hline Drumstick & $\%$ & $\mathrm{~L}$ & 16 & 11.65 & 1.88 & -6.96 & 1.93 & 0.004 & 1.11 & 28.62 & Negative \\
\hline Wing & $\%$ & $\mathrm{~L}$ & 16 & 6.02 & 2.20 & 0.09 & 1.22 & 0.94 & 0.99 & 18.19 & Positive \\
\hline Fat & $\%$ & $\mathrm{~L}$ & 10 & 1.34 & 0.44 & -0.23 & 0.54 & 0.68 & 1.13 & 18.94 & Negative \\
\hline Liver & $\%$ & $L$ & 17 & 3.03 & 0.50 & -0.66 & 0.21 & 0.010 & 1.01 & 26.15 & Negative \\
\hline \multicolumn{12}{|l|}{$\begin{array}{l}\text { Lymphoid organ } \\
\text { weight }\end{array}$} \\
\hline Bursa & $\%$ & L & 15 & 0.92 & 0.58 & -0.28 & 0.09 & 0.010 & 1.30 & 25.76 & Negative \\
\hline Spleen & $\%$ & L & 15 & 0.82 & 0.49 & -0.62 & 0.09 & $<0.001$ & 1.22 & 23.62 & Negative \\
\hline \multicolumn{12}{|l|}{$\begin{array}{l}\text { Amino acid ileal } \\
\text { digestibility }\end{array}$} \\
\hline Lysine & $\%$ & $\mathrm{~L}$ & 5 & 89.52 & 1.48 & -1.33 & 0.50 & 0.08 & 0.77 & 19.82 & Negative \\
\hline Threonine & $\%$ & L & 5 & 64.42 & 19.69 & 6.14 & 6.69 & 0.43 & 0.77 & 35.36 & Positive \\
\hline Isoleucine & $\%$ & $\mathrm{~L}$ & 5 & 85.31 & 1.67 & -2.40 & 0.57 & 0.02 & 0.77 & 20.54 & Negative \\
\hline Leucine & $\%$ & $\mathrm{~L}$ & 5 & 88.20 & 4.04 & -4.77 & 1.37 & 0.04 & 0.77 & 25.85 & Negative \\
\hline Phenylalanine & $\%$ & $\mathrm{~L}$ & 5 & 88.37 & 4.06 & -3.21 & 1.38 & 0.10 & 0.77 & 25.88 & Negative \\
\hline Arginine & $\%$ & L & 5 & 86.79 & 5.45 & -5.07 & 1.85 & 0.07 & 0.77 & 27.66 & Negative \\
\hline Methionine & $\%$ & L & 5 & 92.21 & 1.70 & -2.93 & 0.58 & 0.01 & 0.77 & 20.65 & Negative \\
\hline
\end{tabular}

$\mathrm{SD}=$ Standard of deviation, Max=Maximum value, $\mathrm{Min}=$ Minimum value, $\mathrm{N}=$ Sample size; RMSE=Root means square error, $\mathrm{AIC}=$ Akaike information criterion

The implication from the high heterogeneity mentioned above is that the lymphoid organs were also in large variations (Table-2). Conversely, there was little variation in AA ileal digestibility, with the greatest effect noted in the digestibility of threonine. As the effect of the tannin on AA digestibility was only evaluated in one study with a low level of tannins $(<0.5 \%)$ [34], this finding suggests that protein digestibility was not impaired by such levels. However, high doses of tannin may affect the development of primary and secondary lymphoid organs [14]; a compound within tannin causes a deficiency in protein utilization, leading to impaired immune function [40]. As such, the assumption of essential AA, minerals, and vitamins is decreased in the gut, affecting the growth of the lymphoid organs. Decreasing the lymphoid organ weight could lead to decreased the bursa Fabricius, thymus, and spleen weights [9].

Tannins are considered beneficial natural compounds for broiler chickens, particularly with respect to gut microbiota modulation; however, as additional evidence has been produced, inconsistent results have emerged from different studies. According to the literature, tannin effectively modulates gut microbiota and the immune system $[14,41,42]$; thus, it could potentially be used as a replacement for antibiotics. As such, researchers have expected tannin supplementation to have a growth-promoting effect. Conversely, the present meta-analysis confirmed contradictory results, in which elevating tannin levels almost completely suppressed growth performance, lymphoid organ weights, and AA digestibility. This detrimental effect was mainly due to the ability of tannins to form tannin-protein complexes in the intestine [43], hence reducing the availability of AA for digestion [44]. In addition, as an antinutritional factor, tannins appeared to decrease the secretion of digestive enzymes and their activity. Consequently, a portion of the nutrients cannot be utilized, particularly protein. The decreased AA digestibility may also be explained by a negative feedback mechanism in which undigested nutrients stimulate enzyme secretion, resulting in a decrease of indigenous AA [43]. In general, in broilers, tannin consumption at high doses decreases AA digestibility; a similar result was also reported by Avila et al. [45] and Mansoori and Acamovic [46], particularly for methionine, leucine, and isoleucine. Methionine, with a high affinity for AA [47], may directly reduce mucosal uptake because of a disturbance of the $\mathrm{Na}+$ and $\mathrm{K}+$ pump cotransportation of AAs or indirectly through the inhibition of $\mathrm{Na}+/ \mathrm{K}+$ ATPase [46]. Excessive tannin concentrations decrease AA (mostly leucine and isoleucine) and support growth depression due to the secretion of enzymes by a hyperactive pancreas [48]; this effect would divert these AAs from the synthesis of body tissue protein to the synthesis of these enzymes, which are subsequently lost in the feces.

In the present meta-analysis, the deleterious effects of tannins were more obvious when tannins were supplemented at a higher level. Theprevious research has noted the negative effects of high dietary levels of tannins [24]. For instance, the weight gain and FCR of 42-day-old broiler chickens were 
impaired when they were fed a diet containing $0.56 \%$ and $0.28 \%$ tannins, respectively $[43,49]$; the authors also reported a decrease of aminopeptidase in chickens that were fed a high tannin content. Decreased broiler growth is likely a result of a reduction in AA digestibility but could also be due to a reduction of metabolizable energy [50]. The reduced bioavailability of protein and energy is two key factors that may explain the mechanism through which elevated tannin content decreases some broiler carcass traits [51], which was confirmed in this meta-analysis.

However, we must underline that dietary tannins may be beneficial when added at low levels, especially for antibacterial and immunostimulatory purposes. Over the past couple of years, a positive effect of the inclusion of low levels of tannins has been reported, particularly with respect to the stimulation of antioxidant status, improvement of intestinal morphology [52], positive modulation of intestinal microbiota [41], and improvement of mucosal immunity [53]. Regarding broiler performance, diets with low levels of tannins have been reported to have comparable effects as diets with no tannins. For example, a dietary concentration of $0.12 \%$ has no adverse effect on ileal AA digestibility [43]. Other studies have also reported no substantial effects of low levels of dietary tannins on broiler growth performance and carcass characteristics $[43,44,54]$. This meta-analysis indicates that dietary tannins can have some negative effects on broiler performance, lymphoid organ weight, and AA ileal digestibility.

\section{Conclusion}

This meta-analysis suggests that increasing levels of dietary tannins impair the growth of broiler chickens, which reduces broiler performance; thus, we do not recommend including tannins in broiler diets.

\section{Authors' Contributions}

$\mathrm{CH}$ : Designed the study and collected the data. $\mathrm{CH}, \mathrm{AI}, \mathrm{TRP}$, and YRY: Wrote original draft and reviewed final version of the manuscript. AJ and EW: Reviewed the final version of the manuscript. MMS, SS, RK, and II: Performed formal analysis and data curation. All authors read and approved the final manuscript.

\section{Acknowledgments}

The authors did not receive any funds for this study.

\section{Competing Interests}

The authors declare that they have no competing interests.

\section{Publisher's Note}

Veterinary World remains neutral with regard to jurisdictional claims in published institutional affiliation.

\section{References}

1. Duskaev, G.K., Rakhmatullin, S.G., Kazachkova, N.M., Sheida,Y.V., Mikolaychik, I.N., Morozova, L.A. and Galiev, B.H. (2018) Effect of the combined action of Quercus cortex extract and probiotic substances on the immunity and productivity of broiler chickens. Vet. World., 11(10): 1416-1422.

2. Suresh, G., Das, R.K., Brar, S.K., Rouissi, T., Ramirez, A.A., Chorfi, Y. and Godbout, S. (2018). Alternatives to antibiotics in poultry feed: Molecular perspectives. Crit. Rev. Microbiol., 44(3): 318-335.

3. Mehdi, Y., Létourneau-Montminy, M.P., Gaucher, M., Lou., Chorfi, Y., Suresh, G., Rouissi, T., Brar, S.K., Côté, C., Ramirez, A.A. and Godbout, S. (2018) Use of antibiotics in broiler production: Global impacts and alternatives. Anim. Nutr., 4(2): 170-178.

4. Okuda, T. and Ito, H. (2011) Tannins of constant structure in medicinal and food plants-hydrolyzable tannins and polyphenols related to tannins. Molecules, 16(3): 2191-2217.

5. Sultana, M., Verma, P.K., Raina, R., Prawez, S. and Dar, M.A. (2012) Quantitative analysis of total phenolic, flavonoids and tannin contents in acetone and n-hexane extracts of Ageratum conyzoides. Int. J. Chemtech Res., 4(3): 996-999.

6. McRae, J.M. and Kennedy, J.A. (2011) Wine and grape tannin interactions with salivary proteins and their impact on astringency: A review of current research. Molecules, 16(3): 2348-2364.

7. Azimi, H., Fallah-Tafti, M., Khakshur, A.A. and Abdollahi, M. (2012) A review of phytotherapy of acne vulgaris: Perspective of new pharmacological treatments. Fitoterapia, 83(8): 1306-1317.

8. Marzoni, M., Castillo, A., Franzoni, A., Nery, J., Fortina, R., Romboli, I. and Schiavone, A. (2020) Effects of dietary quebracho tannin on performance traits and parasite load in an Italian slow-growing chicken (White Livorno breed). Animals, 10(4): 1-11.

9. Huang, Q., Liu, X., Zhao, G., Hu, T. and Wang, Y. (2018) Potential and challenges of tannins as an alternative to in-feed antibiotics for farm animal production. Anim. Nutr., 4(2): 137-150.

10. Farahat, M.H., Abdallah, F.M., Ali, H.A. and HernandezSantana, A. (2017) Effect of dietary supplementation of grape seed extract on the growth performance, lipid profile, antioxidant status and immune response of broiler chickens. Animal, 11(5): 771-777.

11. Gambacorta, L., Pinton, P., Avantaggiato, G., Oswald, I.P. and Solfrizzo, M. (2016) Grape pomace, an agricultural byproduct reducing mycotoxin absorption: In vivo assessment in pig using urinary biomarkers. J. Agric. Food Chem., 64(35): 6762-6771.

12. Tandiang, D.M., Diop, M.T., Dieng, A., Yoda, G.M.L., Cisse, N. and Nassim, M. (2014) Effect of corn substitution by sorghum grain with low tannin content on broilers production: Animal performance, nutrient digestibility and carcass characteristics. Int. J. Poult. Sci., 13(10): 568-574.

13. Moyle, J.R., Burke, J.M., Fanatico, A., Mosjidis, J.A., Spencer, T., Arsi, K., Reyes-Herrera, I., Woo-Ming, A., Donoghue, D.J. and Donoghue, A.M. (2012) Palatability of tannin-rich sericea lespedeza fed to broilers. J. Appl. Poult. Res., 21(4): 891-896.

14. Ramah, A., Yasuda, M., Ohashi, Y., Urakawa, M., Kida, T., Yanagita, T., Uemura, R., Bakery, H.H., Abdelaleem, N.M. and El-Shewy, E.A. (2020) Different doses of tannin reflect a double-edged impact on broiler chicken immunity. Vet. Immunol. Immunopathol., 220): 109991.

15. Mannelli, F., Minieri, S., Tosi, G., Secci, G., Daghio, M., Massi, P., Fiorentini, L., Galigani, I., Lancini, S. and Rapaccini, S. (2019) Effect of chestnut tannins and short-chain fatty acids as antimicrobials and as feeding supplements in broilers rearing and meat quality. Animals, 9(9): 1-15. 
16. Manyelo, T.G., Ng'ambi, J.W., Norris, D. and Mabelebele, M. (2019) Substitution of Zea mays by Sorghum bicolor on performance and gut histo-morphology of ross 308 broiler chickens aged 1-42 d. J. Appl. Poult. Res., 28(3): 647-657.

17. Saleh, A.A., Abudabos, A.M., Ali, M.H. and Ebeid, T.A. (2019) The effects of replacing corn with low-tannin sorghum in broiler's diet on growth performance, nutrient digestibilities, lipid peroxidation and gene expressions related to growth and antioxidative properties. J. Appl. Anim. Res., 47(1): 532-539.

18. Bayerle, D.F., Nunes, R.V., Wachholz, L., Bruxel, M.D.O., Geraldo, J., Junior, D.V., Sangalli, G., Giron, T.V. and Schone, R.A. (2019) Use of golden mussel and wattle tannin in the supply of cut chickens. Semin. Cien.c Agrar., 40(5): 1951-1964.

19. Tomaszewska, E., Dobrowolski, P., Klebaniuk, R., Tomczyk, A., Kowalik, S., Milczarek, A. and Management, F. (2018) The influence of dietary replacement of soybean meal with high-tannin faba beans on gutbone axis and metabolic response in broiler chickens. Ann. Anim. Sci., 18(3): 801-824.

20. Abdulla, J.M., Rose, S.P. and Mackenzie, A.M. (2017) Feeding value of field beans (Vicia faba L. var. minor) with and without enzyme containing tannase, pectinase and xylanase activities for broilers. Arch. Anim. Nutr., 71(2): 150-164.

21. Bayerle, D.F., Nunes, R.V., Celso, A., Junior, G., Wachholz, L., Scherer, C. and Mara, I. (2017) Golden mussel (Limnoperna fortunei) in feed for broiler chicks using tannin as a sequestrant of toxic metals Mexilhão dourado (Limnoperna fortunei) na alimentação de pintos de corte utilizando tanino como sequestrante de metais tóxicos. Resumo, 38(2): 843-854.

22. Xu, X., Wang, H.L., Pan, L., Ma, X.K., Tian, Q.Y., Xu, Y.T., Long, S.F., Zhang, Z.H. and Piao, X.S. (2017) Effects of coated proteases on the performance, nutrient retention, gut morphology and carcass traits of broilers fed corn or sorghum based diets supplemented with soybean meal. Anim. Feed Sci. Technol., 223: 119-127.

23. Abdulla, J.M., Rose, S.P., Mackenzie, A.M., Ivanova, S.G., Staykova, G.P. and Pirgozliev, V.R. (2016) Nutritional value of raw and micronised field beans (Vicia faba L. var. minor) with and without enzyme supplementation containing tannase for growing chickens. Arch. Anim. Nutr., 70(5): 350-363.

24. Batonon-Alavo, D.I., Bastianelli, D., Lescoat, P., Weber, G.M. and Faruk, M.U. (2016) Simultaneous inclusion of sorghum and cottonseed meal or millet in broiler diets: Effects on performance and nutrient digestibility. Animal, 10(7): 1118-1128.

25. Hu, Y., Wang, Y., Li, A., Wang, Z., Zhang, X., Qiu, L. and Yin, Y. (2015) Effects of fermented rapeseed meal on antioxidant functions, serum biochemical parameters and intestinal morphology in broilers. Food Agric. Immunol., 27(2): 182-193.

26. Starcevik, K., Krstulovic, L., Brozic, D., Mauric, M., Stojevic, Z., Mikulec, Z., Bajic, M. and Masek, T. (2014) Production performance, meat composition and oxidative susceptibility in broiler chicken fed with different phenolic compounds. J. Sci. Food Agric., 95(6): 1172-1178.

27. Hejdysz, M., Kaczmarek, S.A. and Rutkowski, A. (2015) Factors affecting the nutritional value of pea (Pisum sativum) for broilers. J. Anim. Feed. Sci., 24(3): 252-259.

28. Riasi, A., Mahdavi, A.H. and Bayat, E. (2015) Effect of different levels of raw and heated grass pea seed and on nutrient digestibility, intestinal villus morphology and growth performance of broiler chicks. J. Anim. Physiol. Anim. Nutr. (Berl.), 99(5): 924-931.

29. Rezar, V. and Salobir, J. (2014) Effects of tannin-rich sweet chestnut (Castanea sativa mill.) wood extract supplementation on nutrient utilisation and excreta dry matter content in broiler chickens. Eur. Poult. Sci., 78: 1-10.

30. Konieczka, P., Smulikowska, S., Czerwiński, J. and Mieczkowska, A. (2014) Raw vs extruded coloured-flower pea as an ingredient in broiler diets: Effects on performance, ileal digestibility, gut morphology, and intestinal microbiota activity. J. Anim. Feed Sci., 23(3): 244-252.

31. Torres, K.A.A. Jr., Soares, C.P., Silva, T.G.A., Nogueira, W.C.L., Campos, D.M.B., Furlan, R.L. and Macari, M. (2002) Effects of corn replacement by sorghum in broiler diets on performance and intestinal mucosa integrity. Poult. Sci., 92(6): 1564-1571.

32. Sasipriya, G. and Siddhuraju, P. (2013) Evaluation of growth performance, serum biochemistry and haematological parameters on broiler birds fed with raw and processed samples of Entada scandens, Canavalia gladiata and Canavalia ensiformis seed meal as an alternative protein source. Trop. Anim. Health Prod., 45(3): 811-820.

33. Teteh, A., Lawson, E., Tona, K., Decuypere, E. and Gbeassor, M. (2013) Moringa oleifera leave: Hydroalcoholic extract and effects on growth performance of broilers. Int. J. Poult. Sci., 12(7): 401-405.

34. Brus, M., Gradi`snik, L., Trapecar, M. `Skorjanc, D. and Frange $z$, R. (2018) Beneficial effects of water-soluble chestnut (Castanea sativa Mill.) tannin extract on chicken small intestinal epithelial cell culture. Poult. Sci., 97(4): 1271-1282

35. Jayanegara, A., Sujarnoko, T.U.P., Ridla, M., Kondo, M., Kreuzer, M. (2019) Silage quality as influenced by concentration and type of tannins present in the material ensiled: A meta-analysis. J. Anim. Physiol. Anim. Nutr., 103: 456-465.

36. Hidayat, C., Sumiati, Jayanegara, A. and Wina, E. (2020) Effect of zinc on the immune response and production performance of broilers: A meta-analysis. Asian-Australas. J. Anim. Sci., 33(3): 465-479.

37. Yanza, Y.R., Szumacher-Strabel, M. and Jayanegara, A. (2020) The effects of dietary medium-chain fatty acids on ruminal methanogenesis and fermentation in vitro and in vivo: A meta-analysis. J. Anim. Physiol. Anim. Nutr., 1(1): 1-16.

38. Létourneau-Montminy, M.P., Narcy, A., Lescoat, P., Bernier, J.F., Magnin, M. and Pomar, C. (2010) Metaanalysis of phosphorus utilisation by broilers receiving corn-soyabean meal diets: Influence of dietary calcium and microbial phytase. Animal, 4(11): 1844-1853.

39. Hafeez, A., Männer, K., Schieder, C. and Zentek, J. (2016) Effect of supplementation of phytogenic feed additives (powdered vs. encapsulated) on performance and nutrient digestibility in broiler chickens. Poult Sci., 95(3): 622-629.

40. Marzo, F., Tosar, A. and Santidrian, S. (1990) Effect of tannic acid on the immune response of growing chickens. $J$. Anim. Sci., 68(10):3306-3312.

41. Carrasco, J.M.D., Redondo, E.A., Viso, N.D.P., Redondo, L.M., Farber, M.D. and Miyakawa, M.E.F. (2018) Tannins and bacitracin differentially modulate gut microbiota of broiler chickens. Biomed. Res. Int., 2018: 1879168.

42. Mansoori, B. and Modirsanei, M. (2012) Effects of dietary tannic acid and vaccination on the course of coccidiosis in experimentally challenged broiler chicken. Vet. Parasitol., 187(1-2): 119-122.

43. Woyengo, T.A. and Nyachoti, C.M. (2012) Ileal digestibility of amino acids for zero-tannin faba bean (Vicia faba L.) fed to broiler chicks. Poult. Sci., 91(2): 439-443.

44. Kopmels, F.C., Smit, M.N., Cho, M., He, L. and Beltranena, E. (2020) Effect of feeding 3 zero-tannin faba bean cultivars at 3 increasing inclusion levels on growth performance, carcass traits, and yield of saleable cuts of broiler chickens. Poult. Sci., 99(10): 4958-4968.

45. Avila, S.C., Kozloski, G.V., Orlandi, T., Mezzomo, M.P. and Stefanello, S. (2015), Impact of a tannin extract on digestibility, ruminal fermentation and duodenal flow of amino acids in steers fed maize silage and concentrate containing soybean meal or canola meal as protein source. J. Agric. 
Sci.,153(5):943-953.

46. Mansoori, B. and Acamovic, T. (2007) The effect of tannic acid on the excretion of endogenous methionine, histidine and lysine with broiler. Anim. Feed Sci. Technol., 134(3): 198-210.

47. Charlton, A.J., Baxter, N.J., Lilley, T.H., Haslam, E., McDonald, C.J. and Williamson, M.P. (1996) Tannin interactions with full length human salivary proline-rich protein display a stronger affinity than with single proline-rich repeats. FEBS Lett., 382(3): 289-292.

48. Gilani, G.S., Cockell, K.A. and Sepehir, E. (2005), Effects of antinutritional factors on protein digestibility and amino acid availability in foods. J. AOAC Int., 88(3): 967-987.

49. Torres, K.A.A., Pizauro, J.M., Soares, C.P., Silva, T.G.A., Nogueira, W.C.L. and Campos, D.M.B. (2013) Effects of corn replacement by sorghum in broiler diets on performance and intestinal mucosa integrity. Poult. Sci., 92(6): 1564-1571.

50. del Puerto, M., Terevinto, A., Saadoun, A., Olivero, R. and Cabrera, M.C. (2016) Effect of different sources of dietary starch on meat quality, oxidative status and glycogen and lactate kinetic in chicken pectoralis muscle. J. Food. Nutr. Res., 4(3): 185-194.
51. Córdova-Noboa, H.A., Oviedo-Rondón, E.O., Sarsour, A.H., Barnes, J., Ferzola, P. and RademacherHeilshorn, M. (2018) Performance, meat quality, and pectoral myopathies of broilers fed either corn or sorghum-based diets supplemented with guanidino acetic acid. Poult. Sci., 97(7): 2479-2493.

52. Brus, M., Gradišnik, L., Trapečar, M., Škorjanc, D. and Frangež, R. (2018) Beneficial effects of water-soluble chestnut (Castanea sativa Mill.) tannin extract on chicken small intestinal epithelial cell culture. Poult. Sci., 97(4): 1271-1282.

53. Karaffová, V., Bobíková, K., Levkut, M., Revajová, V., Ševčíková, Z. and Levkut, M. (2019) The influence of Farmatan ${ }^{\circledR}$ and Flimabend $\AA$ on the mucosal immunity of broiler chicken. Poult. Sci., 98(3): 1161-1166.

54. Puntigam, R., Brugger, D., Slama, J., Inhuber, V., Boden, B. Krammer, V., Schedle, K., Wetscherek-Seipelt, G. and Wetscherek W. (2020) The effects of a partial or total replacement of ground corn with ground and whole-grain low-tannin sorghum (Sorghum bicolor (L.) Moench) on zootechnical performance, carcass traits and apparent ileal amino acid digestibility of broiler chickens. Livest. Sci., 241: 104187 